\title{
ABSTRACTS OF PAPERS CONCERNING HORTICULTURE, PLANT PATHOLOGY AND PEST INVESTIGATIONS OF ANNUAL MEETING OF THE ACRICULTURAL RESEARCH CENTRE IN 1958
}

The following presents abstracts of short lectures dealing with horticultural, plant pathological and pest investigations. These lectures were held at the Annual Meeting of the Agricultural Research Centre at Tikkurila on Feb. 26-27th, 1958.

The control of the pea moth (Laspeyresia nigricana Steph.). Вy S. Екноцм, Depart. of Pest Investigation, Tikkurila. - The experiments carried out in the years $1947-1955$ proved that the larvae of the pea moth (Laspeyresia nigricana Steph.) on garden peas can be succesfully controlled with chemical treatments. The species on field peas is more seldom worth destroying. The best result was received with DDT oil emulsion and almost equally good with parathion spray. - When the cultivation of peas to be tinned was started in Finland, it was quite generally supposed, that the pea moth would rapidly increase in these cultivations. It was, however, noted, that in the areas of cultivation of peas to be tinned the damage caused by the pea moth has considerably decreased. This was due to the fact, that peas to be tinned are harvested in an early stage, when the main part of the larvae is young and are killed. As far as peas to be tinned are cultivated in the same place from year to year the population of pea moths will decrease rapidly. In order to prevent the adults from flying from the pea fields to the cultivations of peas to be tinned these ought to be placed as far as possible from the pea fields, preferably in isolated areas, for example on an island. The essential condition is that peas to be tinned are not cultivated in the same area where peas will be harvested as dried. The use of chemical control substances is then not needed.

Surveys to the results of the investigations regarding the damage to oats in the year of 1957. By O. Heikinheimo, Depart. of Pest Investigation, Tikkurila. - Investigations are continued on to clear out the severe damage to oats caused by Calligypona pellucida (F.) in the western coastal area of our country. The studies were carried out in the field laboratory of Department of Pest Investigation situated at Laihia. Peculiar to the summer 1957 was the obvious slightness of damages in the whole area of damage. This was due to many different factors. In the investigations attention was especially paid to the possible damages of $C$. pellucida in other cultivated cereals. It was stated, that both barley and wheat were damaged, barley slightly and wheat worse. For example in the isolation cage experiments in the field the proportional losses in yield were $20-45$ per cent in spring wheat, $10-20$ per cent in barley, and 
in oats correspondingly $70-94$ per cent. - In variety experiments during last summer no results were received because of the slightness of damages. Experiments consisted fo more than 60 different varieties of oats. The possibilities to find out and breed a resistant variety seem to be difficult, for the species used in the experiments Avena fatua and Avena strigosa were damaged as badly as Avena sativa. - The high potential of reproduction of $C$. pellucida could be established. The average number of the eggs laid by 26 females was 430 . The incubation period lasted $2-3$ weeks. In experiments regarding host plants and their selection it was stated, that $C$.pellucida uses readily all cultivated cereals as its food and oviposition plants. It was stated, that there are two factors influencing on the behavior of leafhoppers with respect to their host plants: firstly, the fitness of the plants differed considerably from each other. If the females were forced to live continually only on timothy even after their emergence, they did not swell as much as the females transferred to oats. It seems obvious that timothy lacks a substance necessary for the leafhoppers to have their ovaries working normally, or in timothy there is some substance that prevents the activity of the ovaries. In the experiments, where the leafhoppers had also oats in addition to timothy, they swelled in few days after their emergence and started their normal oviposition. In these conditions timothy proved to a profitable base for oviposition and when the oats was young the egg laying-was considerably more abundat in the straws of timothy than in oats. The other ley grasses Lolium perenne and Bromus inermis are profitable food plants and bases for oviposition. Agropyrum repens can be included to the same group. Dactylis glomerata, on the contrary, was not profitable in either way. The behavior of the leafhopper towards Alopecurus pratensis was about the same as towards timothy. It was stated that the leafhopper could survive in Stellaria media, whereas Spergula arvensis and Galeopsis spp. were not in the least profitable for the species. In alsike clover it could get along for some time. - The crop rotation has obviously a notable importance for the abundance and the possibilities of living of the leafhoppers. In the experiments it was stated, that timothy is one of the most profitable host plants for the nymphs of the leafhoppers. Living in timothy they hiberate well and develop into adults before the end of June. During the winter the mortality of the nymphs was only 15 per cent in these conditions, while by plowing 85 per cent of the nymphs could be killed. Only 25 per cent of the leafhoppers living in the weed plants survived.

The effect of seed dressing of winter cereals on low-temperature parasitic fungi. By E. A. Jamalainen, Depart. of Plant Pathology, Tikkurila. - According to experiences from seed dressing tests with winter cereals in Finland the small amount of mercury accompaying the seed in the soil affords the seedlings considerable protection from damage by low-temperature fungi during the winter. This action is also indicated indirectly in the treatment of winter cereals seedlings in the late autumn with organic mercury compounds. - In experiments on the seed dressing of winter cereals, carried out in different parts of the country during the period 1928-1950, dressing the seed with mercurial chemicals resulted in an average increase of $19.4 \%$ in winter rye seed yield (131 tests) and $6.1 \%$ in winter wheat seed yield ( 35 tests). The increase in yield was mainly due to the effect of the seed dressings in controlling snow mould [Fusarium nivale (Fr.) Ces.]. In the greater number of the tests the seed germinated 
normally; for this reason in particular the heavy increase in the yield of winter rye cannot be put down to control of seed borne infection by the dressing. With regard to individual tests it can be mentioned, for example, that at Tikkurila in $1955-56$ the action of a metoxyethylmercury chloride seed dressing preparation caused a $140 \%$ increase in the seed yield of winter rye; in the spring the check plots were $50 \%$ damaged with snow mould and the seed dressed plots were $10 \%$ damaged. There was no mould in the seeds during germination in a laboratory test. In this case the amount of mercury present in the field was about $7.5 \mathrm{~g} / \mathrm{ha}$, calculated on a basis of $500 \mathrm{~g}$ seed dressing with $1.5 \% \mathrm{Hg}$ content to one hectare sown with seed. - In experiments with winter cereals during the winter $1955-56$, in which the seedlings were treated with phenylmercuryacetate (Verdasan and Bayer 4426) and salicylmercuryacetate (Mercadmine ad Merculine) preparations during the late autumn, snow mould (Fusarium nivale) damage to winter rye and wheat was entirely or almost entirely prevented, resulting in a considerable increase in the seed yield. It was also to be noted that administration of the preparation only led to the presence of a very small amount of mercury per hectare in the field: $425 \mathrm{~g}$ in the case of the Verdasan preparation, $75 \mathrm{~g}$ in the case of the Bayer 4425 preparation, $235 \mathrm{~g}$ in the case of the PMS Mercadmine preparation, and $470 \mathrm{~g}$ in the case of the Merculine preparation.

On the pests of clover. By M. Markkula, Depart. of Pest Investigation, Tikkurila. - Studying of the pests of clover have been carried out since 1953. Attention has been paid chiefly to the weevils (Curculionidae). The most important seed pests of red clover are Apion apricans Herbst, A. assimile Kirby, and Phytonomus nigrirostris Fabr. These species are very abundant, and they occur as far as in North Finland. Detailed studies on their biology have been carried out. Of the seed pests, Apion trifolii L. (= A. aestivum Germ.) and Phytonomus meles Fabr. are more rare and spread only in concise area. Apion virens Herbst living in the stem of red clover at the larval stage is very general and abundant, too. Other important pests of red clover are Haplothrips niger Osb., Dasyneura leguminicola Lintn., and Ditylenchus dipsaci (Kühn) Filipjev. - The most important seed pests of alsike and white clover is Apion flavipes Payk., which is very abundant and occurs as far as in North Finland. A more rare seed pest is Miccotrogus picirostris Fabr. Apion seniculus Kirby living in the stem of alsike clover at the larval stage is rather common. - Of the Sitona species, S. sulcifrons Thunb., S. decipiens Lindb., S. flavescens Marsh., and S. hispidulus Fabr. are most abundant and important pests of red clover. Less abundant species in clover are S. lineatus L., S. puncticollis Steph., S. suturalis Steph., and S. lineellus Bonsd. The Sitona species feed on the roots and root nodules of clover at the larval stage. The adult weevils cause damage to the clover leaves. - Control experments have been carried out with the laboratory dusting apparatus in the insectarium. Malathion, parathion and DDT were very effective against Apion apricans, A. assimile, A. virens, and Phytonomus nigrirostris. More than ten insecticides were tested in the control of Apion flavipes. Malathion and parathion had the most rapid effect, but also some other insecticides had the effect of 100 per cent. The young Apion adults of the new generation were susceptible to insecticides, but the older ones were more resistant. The hibernated adults died susceptibly in the effect of insecticides. - The effect of malathion was more rapid against Sitona sulcifrons and 
S. flavescens than that of DDT, but the final effect of DDT was better. DDT was also very effective against $S$. lineatus, but weak against $S$. decipiens and S. hispidulus. Increase of the seed yield of red clover have been received in the preliminary field experiments with DDT treatment.

On the control of voles with chlorinated hydrocarbons. By A. MyllymäKI, Depart. of Pest Investigation, Tikkurila. - In autumn 1957 the first control experiments in Finland were made with endrin and toxaphene emulsions, which have for example in Germany given good results. The experimental areas were situated in fields not cultivated for about ten years, the grass growth being in places very rich, in placed not dense and with breaks. The field vole (Microtus agrestis L.) was the most abundant species in all experimental plots, but here and there the continental vole (Microtus arvalis Pall.), too, occurred in spots. In addition to these species there occurred also the bank vole (Clethrionomys glareolus Schreb.) and the wood mouse (Apodemus flavicollis Melch.) in the experimental areas, which species are, however, not taken into consideration when dealing with the results. - The indetification of the population of voles before the trial and the control of results after the treatment were chiefly carried out with killing traps using the line trapping method. The abundance of Microtus species in some experimental plots was rather high, even $39-45$ captured animals were received per 100 traps, in some plots the corresponding number was 33 , in some only $17-25$. The treatments were chiefly carried out with a portable atomizing motor sprayers (Fontan, Solo). Of the amounts of liquid used 120 litres per hectare proved enough even in the experimental areas with most dense growths, in less dense and in growtht with breaks even 60 litres per hectare will do. Using the sprayers of old model the liquid of $400-600$ litres per hectare is needed depending on the density of the growth. A good result in trials was received using the endrin emulsion of 20 per cent 1.0 litre per hectare, the result with 0.7 litres was satisfactory, but the 0.5 litres decreased the population of voles only $40-70$ per cent. On the basis of the results of the trials the amount of 1.0 litre per hectare can be recommended for the present in control of the field vole and continental vole. Of toxaphene treatment $(4.0,5.0$, and 6.0 litres per hectare) a part remained without control because of snowfall, but in those plots, where the check trapping could be made, the result was fairly similar as with endrin emulsion of 0.7 litres. The control experiments of the water vole (Arvicola terrestris L.) with chlorinated hydrocarbons are not yet made in our country, but in the experiments of the year 1958 a special attention will be paid to the possibilities in controlling of this pest with endrin and toxaphene. The first endrin preparation intended for the control of voles will come into sale in Finland in autumn 1958. The Department of Pest Investigation advises to make the endrin treatments in gardens in late autumn after the harvest of fruit. In spring control only poisoned baits are advised to be still used.

Horticultural experiments commenced at Lepaa Horticultural College. By KIRSTI Osara, Depart. of Horticulture, Piikkiö. - Horticultural experiments were started at Lepaa Horticultural College in 1957, in accordance with the College's wishes. Lepaa is situated in the interior of the country (lat. 61/) and as it is considerably farther north than the Department of Horticulture at Piikkiö, it offers good possibilities for comparing of the results experiments with the same 
plant species and varieties. In 1957 Lepaa Horticultural College had a total area of approx. 31.5 ha, of which 4.2 ha consisted of fruit and berry cultivation and 3.8 ha of nurseries. 2.2 ha was reserved for outdoor vegetable gartening. The area for the cultivation of demonstration plants and for experiments, as well as that for outdoor gartening connected with the greenhouse cultivation, occupied about 0.6 ha altogether. The area under glass at Lepaa is nearly $3000 \mathrm{~m}^{2}$, the ordinary greenhouses occupying $1750 \mathrm{~m}^{2}$ and the frames about $1200 \mathrm{~m}^{2}$. The possibilities for arranging experiments at Lepaa are thus particularly good both outdoors and in the greenhouses. In 1957, the first year in which experiments were made, attention was paid chiefly to trials with vegetables grown outdoors. At that time weather conditions were not favourable for the cultivation of tomatoes. Sweet corn did not ripen. Both crisphead lettuce and butterhead lettuce as well as broccoli, turned out well at Lepaa. In 1958 additional experiments have been arranged in the greenhouses, too. Varieties of tomato resistant to leaf mould (Cladosporium fulvum Cooke) and of different Fi hybrids of cucumber are under trial. Chrysanthemums are being cultivated in accordance with "short day treatment". In addition the effects of gibberellic acid, the substance obtained from the fungus Gibberella fuiikuroi, on plants are being investigated. The only berry-bearing plant under studying is strawberry, with which variety tests have been arranged. The new variety Senga Sengana is an item of interest. In addition to their general aim, the horticultural experiments carried out at Lepaa also have an educational significance, offering as they do an opportunity to the students of the College and gardeners School to acquaint themselves with new methods of cultivation and new horticultural plants.

Experiments with vegetables. By Kirsti Salokangas, Depart. of Horticulture, Piikkiö. - In the variety experiments with greenhouse tomatoes performed during the last three years, special attention was paid to varieties resistant to tomato leaf mould (Cladosporium fulvum Cooke). Experiments were made with 9 varieties, Potentat $\mathrm{AH} 8$ being used as standard variety. A Weibull's variety Immuna $\mathrm{F}_{1}$ hybrid proved to be fully resistant to tomato leaf mould and, in addition, it was earlier and gave a heavier crop than the standard variety. A new Norwegian Kvithamar $F_{1}$ hybrid is also worthy of note, having an earlier and heavier crop than the original Kvithamar variety. Further, the size of the fruit is bigger in the hybrid. Both Kvithamar varieties suffer easily from magnesium deficiency. - In experiments with cabbages an attempt was made to determine which of the vast number of varieties at present available were suited for cultivation in Finland. On the basis of a series of experiments made during the last three years, the cabbage varieties Golden Acre and Toftegård A.H. No. 53 proved to be the earliest, yielding $50 \%$ of their crop as early as July. The total yields were of approximately the same value. In August the best yield from the medium early cabbages was given by Ruhm von Enkhuizen, its average yield being $564 \mathrm{~kg} / \mathrm{a}$. During the same three-years period a slightly later variety, Länsipohja, gave an average yield of $495 \mathrm{~kg} / \mathrm{a}$. Of the late cabbage varieties the Amager strains are the most generally cultivated in Finland to date. In experiments where the Amager Halvhög was the standard, the variety Staup 17 and the Faales blåtopp strains gave better yields than the standard variety. In storage tests with cabbages the Jåtunsalgets vinterkål varieties kept the best, 
the losses by storage during the course of $4 \frac{1}{2}$ months being $36 \%$, while the losses by storage in Staup 17 were $37 \%$. The losses by storage in the Faales blåtopp strains varied between $42-51 \%$. The Amager låg variety decayed the most during storage, the losses being $66 \%$. - In experiments to investigate techniques for cultivating cabbages a comparative examination was made of the transplanting of cabbage seedlings to frames, to clay pots, to paper pots, to huminal pots, to soil blocks compressed by potting machines, and to peat blocks. The seedlings in the huminal pots developed best and also gave the earliest yield. During the first ten days of harvesting the yield from the seedlings transplanted to the huminal pots was $45 \%$ of their total yield, the yield from those transplanted to the paper pots $36 \%$, from those transplanted to soil blocks $25 \%$, to clay pots $23 \%$, to peat blocks $14 \%$, and to frames $6 \%$. The use of polyethylene film covers in the cultivation of early cauliflower was investigated. The seedlings were protected after setting by polyethylene film frames, the height to the top of which was $70 \mathrm{~cm}$. The polyethylene film used was $0.15 \mathrm{~mm}$ thick. According to the experimental figures, the yield from the plants under the film covers during the first ten days of harvesting was $69 \%$ of their total yield, while the corresponding yield from the plants grown out-of-doors was $54 \%$. The yield from the plants under film covers was also better in quality. - Onion sets imported from abroad were compared with onion sets grown and stored by the Department of Horticulture. The material imported from abroad consisted of the Dutch Liva and the Swedish Meteor. Measurement of the diameters of the onions gave three ranges of size: $22 / 25 \mathrm{~mm}, 15 / 22 \mathrm{~mm}$ and $10 / 15 \mathrm{~mm}$. The domestic -grown strains consisted of Autumn Queen, Rijnsburger and Zittauer. Experimental results showed that domestic-grown onion sets can produce a yield that corresponds to the yield from onion sets imported from abroad. The size of the set affects the quantity of its yield. In consideration of the cost of the sets, it is most profitable to cultivate onion sets of $15 / 22 \mathrm{~mm}$ diameter.

Atlas, a Canadian variety of apple. By J. SÄKö, Depart. of Horticulture, Piikkiö. - The Atlas apple variety originates from Canada, from the Central Experimental Farm in Ottawa, where it had grown from open pollinated seeds of the Winter St. Lawrence tree and selected for observation in 1912. In 1924 the Atlas apple was introduced commercially for the first time. The climatical hardiness of the variety proved to be good in Canada, and it has for instance, turned out successfully in the prairie districts which are unfavourable to fruit cultivation. The first Atlas trees in the observation orchard of the Dapertment of Horticulture were planted in the autumn of 1942. Their hardiness, as well as that of trees planted later, has proved good during overwintering. This good climatical hardiness of the variety is also mentioned in reports received from South Savo Experiment Station at Mikkeli where the Atlas trees is stated to have successfully survived the very severe winter of 1955-56. Similarly, the variety exhibited good winter hardiness at the Häme Experiment Station at Pälkäne (in the southern part of Central Finland). On these grounds the Atlas apple may be regarded as climatically hardy in the southern parts of Finland at least, but probably even in the Finnish fruit farming zone III, situated approximately between latitudes $61^{\circ}-62^{\circ}$. The Atlas tree has a vigorous growth. At first its growth is comparatively upright, but the tree soon spreads as it becomes 
older. The crown formation consists of particularly strong open crutches. The branches seldom break, in spite of heavy crops. The variety crops both early and heavily. At the Department of Horticulture Atlas trees have given noticeably large total yields. Thus 15 years after planting, the cumulative yield was $1031 \mathrm{~kg}$ per tree. The best tree produced $1141 \mathrm{~kg}$ apples during this period. It is to be noted that Atlas is not a biennial bearing variety, but gives a heavy yield annually. To exemplify this the yields from the best Atlas tree during the last five years (1953 $-57)$ are presented: the figures are 120, 229, 202, 169 and $210 \mathrm{~kg}$. The apples are high in shape, conical and slightly ridged. The eye is closed, the eye basin and the cavity are shallow, and the stem is medium. The fruit skin is greenish, with red stripes on the side exposed to the sun. There is also a red sport, called the Red Atlas. The difference between the colour of this last-mentioned fruit and that of the ordinary Atlas apple is about the same as in the case of the Bergius and Sävstaholm apples. The Atlas apples have a pleasant taste, being juicy and slightly acid. They are good dessert and cooking apples. The average weight of the apple is nearly $100 \mathrm{~g}$. In storage tests with Atlas apples it was proved that in ordinary ventilated storage places they keep well until they go on the market at the beginning of December. In January the taste of the apple and its ability to keep begin to deteriorate. In dry storage places the apples shrivel easily. The variety's weakness lies in its tendency to apple scab. However, when a good timing is used in control of the infection, the Atlas apple can be kept completely free from scab. At the Department of Horticulture $4-6$ sprayings carried out at the beginning of the summer sufficed for this.

The chemical thinning of apples. By J. SÄкö, Depart. of Horticulture, Piikkiö. During the last three years the Department of Horticulture has been carrying out experiments with chemical thinning agents. The varieties used in these tests were Transparente blanche, Melba, Bergius, Snygg, Kaneli, Åkerö and Wealthy. The experiments attempted to determine the effects of spraying with DNOC, naphthalene acetic acid and naphthalene acetamide at different times, and using different concentrations of the spray solutions. The effect of spraying varied in the different varieties. Thus in 1955 a $20 \mathrm{ppm}(0.002 \%)$ naphthalene acetic acid solution caused overthinning in the Snygg variety, but gave satisfactory results with the Bergius variety. The spraying had no effect on the Weatlhy variety. Spraying was performed 7 days after the calyx stage. In the other years the best results with naphthalene acetic acid were obtained by spraying as soon as possible after the calyx stage. The concentration of the spray solution was then $20-30 \mathrm{ppm}$. In the Wealthy variety no noticeable effect was obtained until the concentration used was as high as $40 \mathrm{ppm}$. When treated immediately after flowering foliage injury appeared in Transparente blanche, Kaneli and Åkerö trees. Spraying performed two weeks after the calyx stage did not lead to the appearance of injury, but its thinning effect was slight. On the other hand, foliage injury was not observed when these varieties were sprayed with naphthalene acetamide $(50 \mathrm{ppm})$ immediately after flowering. Serious foliage injury was caused by the DNOC preparation Celinone $(0.1$ and $0.05 \%)$ and by Elgetol $(0.125 \%)$ when applied during flowering. These preparations were not effective enough as thinning agents.

Storage experiments with potatoes, cabbages and carrots. By P. TALviA, Depart. 
of Plant Pathology, Tikkurila. - In the experiments IPC (isopropyl-N-phenylcarbamate) preparations were shown to be the best preventatives of sprouting in potatoes. For example, no sprouting appeared at all in an experiment in which potatoes, after lifting, were sprinkled with $6 \mathrm{~g}$ IPC $/ 100 \mathrm{~kg}$ potatoes and stored in boxes covered with paper in a warm cellar at $10-16^{\circ} \mathrm{C}$ for eight months, until the end of May. Even sprinkling with $4 \mathrm{~g} \mathrm{IPC} / 100 \mathrm{~kg}$ potatoes prevented sprouting until August, when the potatoes were stored in a cold cellar $\left(3-12^{\circ} \mathrm{C}\right)$. - In experiments to study the preventation of sprouting in potatoes by maleic hydrazide preparations, the ingredients were sprayed on to the potato leaves in the autumn. Spraying performed about six weeks before lifting gave the most effective results. These ingredients were not capable of entirely preventing the potatoes from sprouting. In addition, as the potato leaves may be so badly damaged by potato blight and early autumnal frost that their spraying only results in slight prevention of sprouting in the stored potatoes, permission has not been granted for the sale of these preparations in Finland. - Storage experiments with cabbage have been carried out during the last three years. In these experiments the preservative ingredients, i.e., PCNB (pentachloronitrobenzene), TCNB (tetrachloronitrobenzene) and IPC preparations, did not prevent the cabbages from decay which was chiefly a result of bacterial action. From this it appears that preservative preparations are hardly of significance in the storage of cabbages. The percentage weight of decay in the experiments was about 20 both in the controls and in the groups treated with preservatives. - I storage tests with carrots, carried out over a period of many years, the results of which have recently been published (Jaakko Mukula: On the Decay of Storeed Carrots in Finland. Acta agricult. Scandinavica, 1957), TCNB preparations prevented or greatly inhibited the action of gray mould (Botrytis cinerea Pers.) and cottony rot [Sclerotinia sclerotiorum (Lib.) Bref.] in causing the carrots to decay. The effect of PCNB in preventing decay was considerably less.

On the control of gray mould in strawberries. By EEva TAPIO, Depart. of Plant Pathology, Tikkurila. - In the experiments carried out in 1955-57 on the control of gray mould (Botrytis cinerea Pers.) in strawberries, each year captane preparations (Flit 406, Orthocide 50, Orthocide $10 \mathrm{P}$ ) and thiram preparations (Pomarsol forte) were used ( 5 tests in all), Actidione was used in 3 tests and Griseofulvin in 2 tests. In most cases the ingredients used in the experiments reduced the amount of gray mould in the berries. The captane and thiram preparations were the most effective, reducing the percentage of gray mould by 13.0 and 13.4; in the controls $24.5 \%$ of the fruit were mouldy on an average. - As experiments carried out in other countries have shown, the plant protection ingredients used in controlling gray mould in strawberries also noticeably increased the yield of fruit. There was an increase of $37 \%$ in the average yield of strawberries treated with captane, and of $15 \%$ in the yield of fruit treated with thiram. Actidione also caused a marked increase in the yield $(28 \%)$, but the effect of Griseofulvin was only slight. In 1957 an investigation was made of the effect of the control ingredients on the taste and external appearance of strawberries stored in different ways. The taste of the fresh berries was not spoiled by captane to any extent worth mentioning; some deterioration in the taste was caused by thiram, and a considerable deterioration by Griseofulvin. There were no 
clear differences in the case of deep-frozen fruit. On thawing, the treated berries looked somewhat grayer as the untreated, but in the control there were twice as many berries $(22.2 \%$ ) attacked by Rhizopus sp. mould than in the berries treated with captane and thiram (11.4 and $10.9 \%$ ). Clear differences were noted in strawberry preserves and in the bottled fruit. Captane was found to give a flavour both to strawberry preserves and to the bottled fruit. The berries did not look as attractive or as fresh as the untreated ones, either, but were somewhat grayish in appearance. Thiram did not cause flaws in taste or external appearance. Griseofulvin somewhat spoilt the taste and external appearance of the bottled fruit, but not of the preserves.

The damage of the frit fly (Oscinella frit L.) in the spring and winter cereals on the basis of the examinations in 1948-1947. By KATRI TIITtAnen, Depart. of Pest Investigation, Tikkurila. - The damages in the sprouts and heads of the spring cereals and in the sprouts of the winter cereals caused by the larvae of the frit fly were examined yearly of the samples received from the Experimental Stations. The same examinations were also made of the experiments at the Department of Plant Husbandry and of the cultivations of Agricultural Research Centre at Tikkurila. The spring cereals. The damages in the sprouts of the spring cereals caused by the larvae of the spring generation of the frit fly were considerably greater than the damages in the heads caused by the larvae of the summer generation. The damage in the sprouts of oats was on an average 8.9 per cent (the number of the samples examined 89 ), in panicles 0.5 per cent (116 samples), in the sprouts of barley 8.4 per cent (102 samples), in heads 1.6 per cent (188 samples), and in the sprouts of the spring wheat 5.2 per cent (101 samples), and in heads 0.02 per cent (109 samples). When the spring cereals were generally sown as early as the beginning of sowing works was possible in spring, the damages in the sprouts and heads caused by the frit fly were of slight importance. Only in some exceptional cases great damages occurred in the early sowings, too. - The winter cereals. The sprouts of the winter cereals are damaged by the larvae of the autumn generation of the frit fly. Especially the early sowings, sown before August 24th, often become damaged completely during the autumn. For this reason the last days of August are recommended as a more suitable time for the sowing of rye and the first week of September for the sowing of the winter wheat. The sowings of the winter cereals were also carried out at these times in the years of investigation. The damage in rye was on an average 3.6 per cent (43 samples) and in the winter wheat 3.7 per cent ( 33 samples). It was only in autumns 1951 and 1955 that there occurred more notable damages also in the sowings carried out at the times recommended, in the first mentioned year at Tikkurila and Pälkäne (in Central Finland) and in 1955 at Tikkurila, Pälkäne and Ylistaro (in the western part of Central Finland). - The samples taken from the sowing time experiments with rye at Tikkurila, Pälkäne and Ylistaro, and from the sowing time experiments with wheat at Tikkurila were examined in years $1947-1957$. The results received in the experiments of the sowing time with rye showed clearly, that the sowings carried out before August 28th often became damaged almost completely. It showed also, that in those years when frit fly does not occur abundantly, the yield received from these early sowings were the richest. The low precentage of damage 
of the frit fly in the sprouts does not act upon the yield. Although 20 per cent of the shoots were damaged in autumn, the yield did not decrease. In the autumns disadvantageous to the development of the frit fly (when it was since the end of August cool and rainy), 40-50 per cent of damaged shoots could exist in the early sowings, in some cases even $60-70$ per cent, without decreasing the yield. - On the basis of a good yield received most certainly with the early sowings in those years the frit fly did not occur abundantly, it is worth investigation to study the possibilities to the chemical control of the frit fly in the winter cereals, especially in rye. (The low yield of the early sowings of winter wheat cannot alwyas be considered as to be caused by the frit fly on the basis of the sowing time experiments at Tikkurila.) It is most desirable that a ufficient result in control of the frit fly would be received with the seed dressing.

Results on the field experiments for control of the cabbage and turnips root flies and the onion fly in 1957. By Katri Tirttanen, Depart. of Pest Investigation, Tikkurila. - In the field experiments for control of Hylemyia brassicae Bouche and Hylemyia floralis Fall. there were used as trial plants the cabbages (Ditmarsk and Low Amager), the cauliflower (Erfurt's Dwarf) and the broccoli (De Cicco) at Tikkurila; the cauliflower (Lange swedish W:s/49 Orig) at Piikkiö, and the cabbage (Ruhm von Enkhuizen) at Rovaniemi. The following dusts were used in the control: aldrin (active substance 2.5 per cent), lindane ( 0.65 per cent), parathion ( 1.5 per cent), and DDT ( 5 per cent), and the following sprays: aldrin ( 20 per cent), lindane $(10$ per cent), parathion (33.3 per cent) and DDT (20 per cent). A part of the treatments were planned for the reared and a part for the unreared plants. - The damages of the maggots on the plants reared in pots or in pressed cubiform clods of soil were prevented by mixing 3 grammes of aldrin or lindane dusts per 1 litre of soil in the rearing soil or by watering the potted plants with the liquid of aldrin or lindane (both 0.2 per cent) or parathion ( 0.05 per cent) just before planting them in open ground. The watering must be thorough going, about 50 cubic centimetres per a plant. Aldrin used in the way mentioned above protects the plants sufficiently against the damages of the maggots the whole summer. Also the results with lindane are satisfactory, but the watering with parathion is preferably recommended only to the early varieties of cabbages, for the effect of parathion is not sufficient against, the maggots occurring in late summer. - Parathion and DDT dusts and DDT spray used in this way did not give sufficient results. - Aldrin, lindane, or parathion dusts strewed in the planting holes, 2 grammes per a plant, proved to be the best treatment against the maggots on the plants unreared or reared in a bed. Also the treatment of the roots in wet soil mixture of aldrin or lindane (both 0.2 per cent) or parathion $(0.05$ per cent) before the planting has given a good result. The growth point of plants must, however, not fall into the insecticide and wet soil mixture. Of the varieties used in the experiments the yield of the cauliflower (Stor svensk W:s/49 Orig) and the cabbage (Ruhm von Enkhuizen) decreased when the roots of the plants were treated with insecticide and wet soil mixture. In this case, too, parathion is used rather to the early varieties. - The same treatments effective against the maggots have given sufficient results against the wireworms.

In the field experiments for control of the onion flies (Hylemyia antiqua Meg.) 
on seed onion the variety Zittauer was used at Tikkurila and the variety, Autumn Queen at Piikkiö. The experiments on set onions were made at Tikkurila, Ylistaro and Rovaniemi with the native strains of multiple onion (from Hytti, Ylistaro, Pudasjärvi and Kemi), Schalotten onion from Holland, and Liva and Meteor set onions of different sizes. The substances used in control experiments were the same as those used in the control experiments of cabbage and turnips root flies. In addition to these there were used the dusts of dieldrin ( 2 per cent) and chlordane (10 per cent) and the sprays of dieldrin and chlordane (both 20 per cent). - The seed dressing with the dusts of aldrin, dieldrin, and chlordane gave good results (the effect 99.599.7 per cent) against the onion maggots on seed onion. The seed dressing were carried out by damping the seeds first with water ( 5 millilitres water per 100 grammes seeds). After that the seeds were mixed (in a bottle) with the dusts mentioned above as much as could be stuck on the surface of the seeds. If the weather is very dry and warm during the germination and sprouting, the seed dressing can cause disturbances in growth, but the watering will soon remedy the situation. - In the experiments on set onions the sets were dipped in the liquid of dieldrin, aldrin, chlordane (all these 2.5 per cent), parathion ( 0.3 per cent), lindane ( 1.5 per cent), and DDT ( 2.5 and 5 per cent) for 2 minutes. The dieldrin treatment gave the best results against the larvae of onion flies and lesser bulb flies (Eumerus strigatus Fall. and E. tuberculatus Rond.), but the other substances, too, were satisfactory. DDT and lindane had a harmful influence on the growing of onions. The onion fly was so small in number in some experiments, that to make the reliability of the results more confident the experiments on set onion will be partly repeated.

On the influence of freezing upon some plant protection chemicals. By A. TINNILÄ, Depart. of Pest Investigation, Tikkurila. - The intention with the test series carried out at the Department of Pest Investigation in years 1956-1957 was to clear up, in what degree the plant protection chemicals kept in open air and frozen lose their usability. The preparations belonging to the most important group of chemical control substances were kept in a store sheltered only against rain during the period of November 15th in 1956 and April 30th in 1957. The average temperatures during the period of storage were per each month the following: $-4.2,-2.2,-2.6,-2.6$, -7.0 , and $+1.6^{\circ} \mathrm{C}$, the average temperature of the whole period of storage being $-2.7^{\circ} \mathrm{C}$, the minimum $-30.2^{\circ} \mathrm{C}$ and the maximum $+16.9^{\circ} \mathrm{C}$. The humidity of the store variated according to the weather conditions in open air. The checking amounts of the preparations were kept in the dry store of poisons, in about $+17^{\circ} \mathrm{C}$. - In the physical composition of the dusts distinct changes revealed caused by humidity. Most preparations were more or less cloddy, some of the DDT dusts nearly useless. The dusting with the preparations had become worse and the clods of unequal sizes plugged the dusting apparatus preventing the steady spreading of the preparations. In consequency of drying the dustiness became somewhat better. - Some of the glass bottles containing spray broke as they were frozen. In the dormant sprays containing DNOC, the DNOC and oil were parted while the yellow precipitate settled to the bottom. The preparation did not return to the former state by shaking and did not mix properly when diluted with water. During the spraying it plugged easily the nozzle parts of the sprayer and was too difficult to spread. - The changes occurre 
in effect were studied only regarding oil carbolineums and the sprays of malathion and parathion. The experiments were carried out as concise laboratory experiments. In the control experiment against the winter eggs of red spider (Metatetranychus pilosus $\mathrm{C}$. et $\mathrm{F}$.) were used oil carbolineum containing 30 per cent mineral oil and 50 per cent tar oil as a dilution of 8 per cent. Of about 620 winter eggs 66 per cent hatched in the check, 0.8 per cent treated with frozen preparation and 0 per cent treated with normal preparation. The control of the winter eggs of apple sucker (Psylla mali Schm.) with the preparations mentioned above succeeded in 100 per cent both with frozen and normal preparation. In control against the larvae of turnip sawfly (Athalia colibri F.) were used parathion spray of 10 per cent used as 0.15 per cent, parathion spray of 33.3 per cent, used as 0.05 per cent, and malathion spray of 50 per cent used as 0.2 per cent. After six days the percentages of effect with the preparations mentioned above were the following (the frozen preparation first): parathion $(10 \%) 73$ and 72 per cent, parathion $(33,3 \%)$ both 100 per cent, and malathion 90 and 88 per cent. - It seems apparent that the freezing does not decrease the effect of oil carbolineums and malathion and parathion sprays. Because of the glass vessel liable to break it would be better to keep the preparations in warm stores.

The control of potato scab with PCNB preparations. By A. YLIMÄKI, Depart. of Plant Pathology, Tikkurila. - Since 1954, experiments have been carried out on the control of potato scab (Streptomyces sp.) with PCNB (pentachloronitrobenzene) preparations. The experiments show that by using these compounds, in the form of either dust or solution, it is possible to reduce considerably the damage caused by the infection, but not to prevent it completely. The control can be carried out with the least expense by spreading the chemical in the rows when setting. By this procedure as little as $100-150 \mathrm{~g}$ active PCNB per are will clearly reduce the number of scabby tubers. An amount twice as big reduces the amount of scab by $25-30 \%$. A very big concentration of the preparation, i.e., $800-1000 \mathrm{~g}$ per are, disturbs the growth of the potato plants and diminishes the size of the yield. In addition to controlling potato scab, PCNB treatment also effectively reduces Rhizoctonia disease (Rhizoctonia solani Kühn). The method is too expensive to be carried out in field cultivation, but is suitable for use in garden cultivation.

\section{SE L OST U S :}

PUUTARHA-, KASVITAUTI- JA TUHOELÄINTUTKIMUKSIA KÄSITTELEVÄT ESITELMÄT MAATALOUDEN TUTKIMUSKESKUKSEN KOETOIMINTAPÄIVILLÄ V. 1958

Maatalouden tutkimuskeskuksen koetoimintapäivillä Tikkurilassa helmik. 26-27 p:nä 1958 pidettiin seuraavat puutarha-, tuhoeläin- ja kasvitautitutkimuksia käsittelevăt pienoisesitelmät.

Puutarhatutkimuslaitos, Piikkiö: Kirsti Osara "Puutarhakokeet Lepaan puutarhaopistossa»; Kirsti Salokangas "Vihanneskokeet»; Jaakko Säkö "Atlas, kanadalainen omenapuulajike» ja "Kemiallinen raakileharvennus omenapuillav. - Kasvitautien tutkimuslaitos, Tikkurila: E. A. Jamalainen» Peittauksen vaikutus syysviljojen talvituhosieniin»; Pentti Talvia "Perunan, kaalin ja porkkanan varastoimiskokeista»; Eeva Tapio» Mansikan harmaahomeen torjunnasta»; Aarre Ylimäki "Perunaruven torjunta PCNB-valmisteillas. - Tuhoeläintutkimuslaitos, Tikkurila: Svante Ekholm "Hernekääriäisen torjunnasta;; Osmo Heikinheimo "Katsaus kaurantuhotutkimuksien v. 1957 tuloksiin»; Martti Markkula "Apilan tuholaisista»; Arvo Myllymäki "Myyrien torjunta klooratuilla hiilivedyillä»; Katri Tiittanen 'Kahukärpäsen (Oscinella frit) vioitus kevät- ja syysviljoissa v:na 1948 — 1957 suoritettujen tarkastusten perusteella» ja »Kaali- ja sipulikärpästen torjuntakokeiden antamia tuloksia v. 1957»; Aulis Tinnilä गJäătymisen vaikutuksesta eräisiin kasvinsuojeluaineisiin. 